\title{
KEHARMONISAN KERJA PARA PEREMPUAN PERKASA PEMBUAT GENTING SOKKA KEBUMEN DENGAN PENDEKATAN PENDIDIKAN KEDAMAIAN (PEACE EDUCATION)
}

\author{
Azam Syukur Rahmatullah \\ Universitas Muhammadiyah Yogyakarta \\ E-mail: azamsyukurrahmatullah@yahoo.co.id
}

\begin{abstract}
Abstrak: Membangun keharmonisan kerja yang berbasis keadilan gender tidaklah mudah. Memerlukan kesadaran dan kesepakatan bersama oleh para pekerja, baik pekerja laki-laki maupun pekerja perempuan untuk menuju "satu tujuan" yakni tujuan kedamaian dan ketenangan dalam kerja. Kondisi yang demikian telah dicontohkan oleh para pekerja di area pembuatan genting Sokka Kebumen, yang berupaya menciptakan keharmonisan kerja terutama kepada para pekerja perempuan dengan menggunakan pendekatan pendidikan kedamaian (peace education). Wujud upayanya adalah dengan memaksimalkan peranan paguyuban. Sebab paguyuban menjadi media perekat hubungan sosial yang tinggi antara para pekerja. Selain itu ada upaya keras dari para perempuan pekerja itu sendiri untuk melestarikan budaya harmonisasi kerja yang sejatinya sudah berjalan turun-temurun, yakni dengan cara Pertama, inkulkasi nilai keharmonisan kerja kepada anak yang selalu diterapkan di rumah. Kedua, penteladanaan nilai, yang ditunjukkan langsung oleh para perempuan pekerja pembuat genting dengan cara membawa anak-anak mereka ke lokasi kerja. Ketiga, Pengembangan budaya empati kepada anak-anak mereka.
\end{abstract}

Kata kunci: Keharmonisan kerja, Pekerja Perempuan, Genting Sokka, Pendidikan Kedamaian

\section{PENDAHULUAN}

Bekerja merupakan simbol "perjuangan manusia" dalam memenuhi tanggung jawab moral agama (QS. At-Taubah ayat 105, QS. Fushsilat ayat 5). Bekerja tidak hanya menjadi "hak mutlak" kaum maskulin, tetapi menjadi "hak prerogratif" kaum feminim untuk memilih dirinya bekerjakah, atau tidak (terutama bagi mereka yang telah berkeluarga). Kesemuanya menjadi hak bagi kaum perempuan, dan tidak ada ayat Qur'an sekalipun yang melarang kaum feminim untuk tidak boleh bekerja. Dengan kata lain, bekerja menjadi hak bebas memilih/menentukan bagi kaum perempuan bagi yang telah berkeluarga (Nasarudin Umar dalam buku Siti Ruhaini Dzuhayatin, 2002: 107), dan hak mengembangkan diri atas potensi yang dimiliki, serta hak bekerja serta mengembangkan potensi bagi para perempuan yang belum berkeluarga. Sebab yang demikian telah dijamin oleh Allah sebagaimana kedua surat dan ayat di atas. Konteks "bekerjalah" pada ayat di atas tidak disekat dan disempitkan hanya bagi para kaum laki-laki saja, tetapi diperluas bagi kaum perempuan baik yang sudah menikah maupun yang belum menikah.

Namun demikian, kesejajaran dalam bekerja, bukan semata-mata menghilangkan "etika kesantunan" dalam berumah tangga bagi kaum perempuan. Mereka dituntut untuk tetap meminta ijin bekerja kepada suami sebab terdapat nilai kebarakahan dan kerahmatan manakala ijin suami telah dibuka. Selain itu kaum perempuan tetap diharuskan memenuhi tanggung jawab sebagai istri untuk suami dan anak-anaknya. Serta kaum perempuan tetap 


\section{2-30 | HARKAT: Media Komunikasi Islam Tentang Gender dan Anak, 11 (1), 2015}

diharuskan menghargai suami, meskipun nantinya penghasilan istri lebih tinggi dari suami. (Akhmad Minhaji, dalam buku Siti Ruhaini Dzuhayatin 2002: 186)

Hal yang menjadi kunci keselarasan dan keharmonisan bekerja bagi perempuan, terutama perempuan yang sudah menikah; baik keselarasan dan keharmonisan dalam zona keluarga, maupun keselarasan dan keharmonisan dalam tempat/lokasi di mana mereka bekerja adalah pengembangan budaya damai (peace culture). Aktivitas penuh kedamaian dalam zona keluarga dapat dilihat dengan diperolehnya ijin bekerja dari suami dengan keikhlasan penuh, bahkan mendapatkan dukungan tanpa adanya konflik, keributan dan perdebatan panjang.

Sedangkan budaya damai dalam lingkungan tempat kerja dapat dilihat dengan penghargaan kaum laki-laki terhadap kaum perempuan, tanpa adanya "pembedaan" dan "pengkotak-kotakan" antara pekerja laki-laki dan perempuan-kecuali hanya dilihat dari jenis dan kadar pekerjaannya saja, tetapi secara komunikasi sosial antara pekerja laki-laki dan perempuan terjalin harmonisasi-komunikasi yang damaiselain itu tanpa adanya keributan, iri dengki, saling menyalahkan dan bahkan saling bahumembahu dan tolong menolong.

Kondisi apik nan ideal di atas tercipta pada para pekerja pembuat genting Sokka di Kebumen. Para perempuan perkasa ikut bahumembahu dalam membuat genting dan ikut memikul/membawa bahan baku atau pula genting yang masih mentah ke lokasi pembakaran genting. Hal yang nyata terlihat, manakala si perempuan tidak kuat memikul/membawa bahan baku genting yang masih mentah para pekerja laki-laki dengan siap membantu kesulitan para perempuan untuk mengganti membawa bahan baku tersebut ke lokasi pembakaran. Hal yang demikian sudah menjadi kebudayaan kerja pada area tersebut yang patut diteladani. (Wawancara dengan ibu
Rofiatun, Perempuan pembuat genting Sokka dari Desa Kebulusan, wawancara dilakukan pada tanggal 13 September 2015 di lokasi pembuatan genting Desa Kebulusan, Pejagoan).

Di sisi lain, budaya harmonis kerja terlihat dengan adanya pemberian waktu istirahat yang lebih sering kepada pekerja perempuan oleh para pekerja laki-laki. Dengan kata lain para pekerja laki-laki menyadari diri bahwa membuat genting merupakan pekerjaan kasar dan keras yang membutuhkan energi ektra, sehingga apabila para pekerja perempuan dipaksakan seperti mereka "para pekerja laki-laki" bekerja "full time" tentu tidak mampu, karena itulah mereka memberi kesempatan luas kepada para pekerja perempuan untuk istirahat dengan frekuensi yang lebih sering. (Wawancara dengan ibu Rofiatun, Perempuan pembuat genting Sokka dari Desa Kebulusan, wawancara dilakukan pada tanggal 13 September 2015 di lokasi pembuatan genting Desa Kebulusan, Pejagoan). Tidak ada pemaksaan-kuat oleh pekerja laki-laki kepada pekerja perempuan untuk bekerja menyamai bekerjanya para pekerja laki-laki.

Fakta lain yang terlihat nyata keharmonisannya adalah ketika tahapan proses menuju pembakaran genting Sokka, maka para pekerja laki-lakilah yang aktif bekerja menyusun genting yang akan dibakar. Sedangkan para pekerja perempuan justru tidak diijinkan oleh mereka untuk ikut bekerja membidangi pekerjaan berbahaya tersebut. Sehingga para pekerja perempuan membantu yang sifatnya ringan, seperti halnya membuatkan minuman, makanan atau hanya mengangkat kayu bakar yang akan dimasukkan ke daerah pembakaran genting. Dalam hal ini, para pekerja laki-laki tegas melarang para pekerja perempuan untuk membantu proses penyusunan genting yang akan dibakar, sebab mereka tahu benar resiko pekerjaan yang cukup berbahaya. Dengan kata lain, para pekerja laki-laki sangat menghormati dan sangat melindungi para pekerja 
perempuan.(Wawancara dengan ibu Siti Fatiah, Perempuan pembuat genting Sokka dari Desa Kebulusan, wawancara dilakukan pada tanggal 13 September 2015 di lokasi pembuatan genting Desa Kebulusan, Pejagoan).

Hal lain yang nyata adalah dibolehkannya/adanya ijin suami yang bersifat mencair, artinya suami memberikan hak kerja kepada istri untuk bekerja membuat genting tanpa konflik, dengan catatan "tidak boleh terlalu payah/letih," selain itu tetap mengutamakan anak dan suami. Bahkan yang menghantar serta menjemput istri bekerja adalah para suami, padahal suami bekerja di tempat lain. Di sisi lain ada pula dari mereka yang suami istri bekerja pada tempat yang sama membuat genting Sokka, dan memperlihatkan keharmonisan kerja yang baik.

Melihat budaya keharmonisan kerja yang terjalin apik pada daerah pembuatan Genting Sokka tersebut, menggelitik saya sebagai penulis untuk mengetahui lebih dalam, sebenarnya bagaimana keharmonisan kerja dapat tercipta dengan baik. Siapa sebenarnya yang berperan besar membentuknya dan pendekatan apa yang digunakan. Dalam hal ini penulis akan berupaya membahasnya lebih dalam, sehingga nantinya diharapkan temuan ini dapat dijadikan sebagai sumbangsih untuk menciptakan perilaku harmonisasi kerja yang sama.

\section{PEMBAHASAN}

\section{Mengenal Lebih Dekat Genting Sokka Kebumen dan Eksistensi Pekerja Perempuan Pembuat Genting}

Nama genting Sokka merupakan nama yang cukup masyhur di sepanjang daerah Jawa Dwipa (utamanya Jawa Tengah). Apalagi jika masuk daerah Kebumen, terkhusus mulai dari Desa Sruweng, Klirong, dan Pejagoan sudah berderet rumah-rumah yang menjajakan genteng Sokka. Genting yang terkenal dengan daya tahan lama, awet, dan tidak mahal. Bahkan pemesan genting Sokka tidak hanya berasal dari Wilayah Kebumen saja, tetapi dari luar Kebumen, semisal dari daerah Yogyakarta, Solo, Purwokerto, Cilacap, bahkan lebih jauh seperti Jakarta dan Bandung.

Kemasyhuran nama genting Sokka cukup beralasan, bagaimana tidak? Sejatinya pembuatan genting ini sudah dilakukan sejak tempo dulu yakni pada sekitar tahun 1920-an. Kala itu Pemerintah Belanda melakukan penelitian yang mendalam untuk memetakan daerah-daerah yang memiliki tanah bagus untuk bahan atap bangunan. Salah satu daerah yang terbaik yang memiliki potensi sentra genting adalah Kebumen yang awal pembuatannya berada di Desa Sokka, yang kemudian pada akhirnya disebut dengan genting Sokka.(www. suaramerdeka.com, diakses pada tanggal 15 September 2015)

Menurut sejarah, orang yang membuat genting Sokka pertama kali adalah H. Ahmad, yang pembuatannya menggunakan sistem manual. Bahkan hingga kini masyarakat tidak meninggalkan tradisi pembuatan genting secara manual. Tidak banyak pengusaha genting yang membuat dengan mesin. Meskipun sesungguhnya pembuatan genting dengan mesin sudah diajarkan oleh Pemerintah Belanda yang kala itu dibawa dari Jerman. Sebagai bukti konkreatnya masih ada peninggalan di bekas lokasi pabrik di Dusun Sokka, Desa Kedawung, Kecamatan Pejagoan yakni lima cerobong pembakaran genteng. Meski cerobong tersebut sudah tidak dipergunakan lagi. Di kawasan tersebut nampak pula deretan ruang penyimpanan genteng, termasuk dari bekasbekas rel dari dalam pabrik yang tersambung menuju stasiun Sokka. (www. suaramerdeka.com, diakses pada tanggal 15 September 2015)

Pembuatan genting Sokka sejak dahulu hingga kini dilakukan oleh para pekerja laki-laki, meski tidak sedikit pekerja perempuan ikut berperan aktif membuat genting. Menurut Bapak 


\section{4-30 | HARKAT: Media Komunikasi Islam Tentang Gender dan Anak, 11 (1), 2015}

Saeri (atau dikenal dengan nama Kakek Bentu) pekerja perempuan di era kini tidak sebanyak dahulu alasan yang dikedepankan adalah Pertama, banyaknya perempuan yang lebih memilih kerja halus (soft worked) seperti ibu rumah tangga, atau menjadi pekerja rumah tangga (PRT) atau ada yang lebih memilih kerja di pabrik, yang tentu tingkatannya lebih ringan daripada menjadi pembuat genting. Kedua, banyaknya perempuan-perempuan yang berpendidikan tingkat Menengah Atas atau sarjana, yang menjadikan mereka ada faktor kegengsian diri apabila memilih bekerja menjadi pembuat genting. Ketiga, banyaknya perempuanperempuan muda yang tinggal pada daerah pembuat genting Sokka yang lebih memilih bekerja di kota-kota besar, sehingga rata-rata yang masih berkehendak bekerja menjadi pembuat genting adalah mereka yang rata-rata sudah ibu-ibu, jarang sekali bahkan cenderung tidak ada yang masih muda (usia produktif bekerja). (Wawancara dengan Bapak Saeri (Kakek Bentu), pembuat genting Sokka dari Desa Kebulusan, wawancara dilakukan pada tanggal 13 September 2015 di lokasi pembuatan genting Desa Kebulusan, Pejagoan).

Menurut pengamatan/observasi yang penulis lakukan, para ibu yang menjadi pekerja pembuat genting tidaklah banyak rata-rata tidak sampai sepuluh (10) orang. Meskipun sejatinya tidak sedikit jumlahnya para ibu yang tinggal di daerah sekitar pembuatan genting tersebut. Tetapi tetap saja mereka tidak berkeinginan menjadi pekerja pembuat genting seperti yang dilakukan oleh beberapa ibu lainnya, hal ini dikarenakan ada beberapa sebab, yakni: Pertama, mereka berasumsi bahwa menjadi pembuat genting merupakan pekerjaan kasar, yang tentunya membuat mereka cepat lelah, effect-nya apabila mereka lelah akan berdampak kepada pengurusan rumah tangga yang kurang maksimal. Kedua, mereka lebih mengandalkan gaji/keuangan dari suami, meski dirasa kurang, tetapi mereka tetap memilih berhemat daripada harus menjadi pekerja kasar. Ketiga, mereka tetap hanya ingin menjadi ibu rumah tangga, yang fokus mengurusi anak di rumah.

Adapun alasan para ibu yang rela dirinya menjadi pekerja kasar membuat genting Sokka, yakni: Pertama, tidak ada pilihan lain, mereka mencari kerja yang terdekat dengan tempat tinggal mereka, karena mereka tidak berkehendak meninggalkan anak dan suami untuk bekerja di tempat yang jauh. Kedua, mereka merasa tidak memiliki kemampuan lain, kecuali hanya membuat genting, menjadi ibu rumah tangga di sekitar tempat tinggal mereka tergolong sulit, hal ini dikarenakan "tidak banyak" orang kaya yang ada di daerah mereka, kalaupun ada, sudah memiliki pekerja rumah tangga. Kondisi yang demikianlah yang pada akhirnya menjadikan mereka menjadi pembuat genting Sokka. Ketiga, karena kondisi ekonomi yang menjadikan mereka harus melakukan "kerja kasar." Dengan tujuan membantu keuangan keluarga dikarenakan penghasilan suami belumlah mencukupi untuk kebutuhan seharihari. (Wawancara dengan ibu Rofiatun, Perempuan pembuat genting Sokka dari Desa Kebulusan, wawancara dilakukan pada tanggal 13 September 2015 di lokasi pembuatan genting Desa Kebulusan, Pejagoan).

Pada tataran realita, para pekerja perempuan perkasa di daerah Sokka tidak mau tertinggal untuk mengembangkan eksistensi diri, meski eksistensi diri yang dikedepankan adalah "eksistensi jantan" (masculine), disebut demikian karena mereka mengerjakan pekerjaan yang kasar, kuat dan melelahkan. Tetapi mereka tetap menjalankan dan menunjukkan kemampuan mereka dengan baik meski tetap tidak meninggalkan kodratnya sebagai makhluk perempuan yang lembut, halus dan lemah gemulai. Sehingga selama mereka bekerja tetap pada koridor-koridor keperempuanannya, dan yang demikian menjadi permakluman tinggi bagi para pekerja laki-laki. Mereka (para pekerja laki- 
laki) tidak menggunakan kekuasaan, keperkasaan serta superpower-nya terhadap para pekerja perempuan, dan tidak pula menggunakan asas "adigang adigung adiguna." Hal inilah yang menjadikan para pekerja perempuan pembuat genting Sokka merasa terayomi, merasa dimanusiakan serta merasa dihargai sebagai pekerja perempuan.

\section{Daya Cipta "Keharmonisan Kerja Berbasis Keadilan Gender" pada Area Pembuatan Genting Sokka Kebumen}

Sesuai penelusuran penulis pada wilayahwilayah sentra pembuat genting Sokka Kebumen, penulis menjumpai "perilaku harmonisasi kerja” yang sama baik di desa Pejagoan, Sruweng maupun Klirong. Maksud harmonisasi kerja yang sama adalah rata-rata para pekerja laki-laki dengan pekerja perempuan terjalin harmonisasi kerja yang santun, damai dan melekat (attachment). Hal ini dibenarkan dengan pernyataan Muhammad Baedlowi yang menyatakan bahwa masyarakat pembuat genting Sokka di berbagai sentra area memang memiliki tingkat kesadaran yang tinggi perihal bagaimana memperlakukan pekerja perempuan, mereka tidak akan memaksakan para pekerja perempuan untuk terus bekerja manakala kekuatannya sudah melemah. Bahkan mereka cenderung mempersilahkan para pekerja perempuan untuk lebih banyak mengistirahatkan diri di area pembuat genting, yang setelah pulih kekuatannya kemudian bekerja kembali.(Wawancara dengan Muhammad Baedlowi merupakan pengamat bisnis genting di Kebumen, dan dia selalu mengamati bagaimana pembuatan genting Sokka yang dilakukan oleh para perempuan pekerja pembuat genting. Wawancara dilakukan pada tanggal 14 September 2015 di Kebumen).

Hal ini ditegaskan pula oleh Ibu Munginah yang menyatakan bahwa kekuatan para pekerja perempuan tidak sama dengan kekuatan yang dimiliki oleh para pekerja lakilaki, meski secara hak kerja sama tetapi secara kekuatan fisik berbeda, apalagi perkerjaan membuat genting adalah pekerjaan fisik, sehingga rata-rata para kaum pekerja laki-laki secara otomatis menyadari diri untuk tidak memperlakukan pekerja perempuan kecuali sesuai batas-batas kemampuannya. (Wawancara dengan ibu Munginah, Perempuan pembuat genting Sokka dari Desa Klirong, wawancara dilakukan pada tanggal 14 September 2015 di lokasi pembuatan genting Desa Klirong).

Salah satu media yang menjadikan terciptanya harmonisasi kerja berbasis keadilan gender adanya "paguyuban kerja" para pekerja pembuat genting Sokka. Meski paguyuban tersebut tidak bersifat formal (artinya tidak dipatenkan ke dalam ranah hukum; seperti tidak selalu memberi nama paguyuban atau diaktanotariskan) tetapi keberadaannya mampu menjadikan suasana kerja menjadi semakin guyub, rukun, hangat serta damai. Paguyuban inilah yang menjadi pondasi utama yang menciptakan visi dan misi yang sama untuk menghargai para pekerja perempuan. Dengan kata lain, paguyuban menjadi media daya cipta keharmonisan kerja berbasis keadilan gender pada para pekerja pembuat genting, yang tentu saja hal ini menjadi keberpihakan positif bagi para pekerja perempuan.”

Menurut Ibu Siti Fatiah bahwa dengan keberadaan paguyuban yang aktif mengadakan arisan dan pertemuan-pertemuan, menjadikan suasana menghangat. Di paguyuban tersebut itu pula, terjalin kekeluargaan yang harmonis baik antara sesama pekerja laki-laki, atau dengan pekerja perempuan, atau pula dengan keluarga dari para pekerja. Selain itu, melalui perkumpulan di paguyuban tercipta kesepakatankesepakatan bersama, yang salah satunya adalah kesepakatan yang berkaitan dengan "bagaimana bersikap terhadap para pekerja perempuan.” Hal ini menunjukkan bahwa paguyuban yang dibuat meski tidak dipatenkan dalam hukum, nyatanya paguyuban tersebut menjadi "paguyuban yang 


\section{6-30 | HARKAT: Media Komunikasi Islam Tentang Gender dan Anak, 11 (1), 2015}

hidup”, bukan "paguyuban yang mati”. Artinya paguyuban tersebut benar-benar menjadi media pengembangan diri dan media pemecah masalah (problem solving) bagi para pekerja pembuat genting Sokka yang bersifat aktif bukan pasif. (Wawancara dengan ibu Siti Fatiah, Perempuan pembuat genting Sokka dari Desa Kebulusan, wawancara dilakukan pada tanggal 13 September 2015 di lokasi pembuatan genting Desa Kebulusan, Pejagoan).

Hal ini memperlihatkan kentalnya budaya damai (peace culture) dalam kerja, meskipun mereka bukan "orang-orang yang berpendidikan tinggi” serta bukan orang-orang yang berkecimpung dalam ranah pemikiran, tetapi perilaku mereka memperlihatkan kedewasaan dalam kerja. Hal yang berkembang dalam keseharian mereka adalah peace culture dan peace action. Terjadi keselarasan yang kuat antara peace culture dan peace action, di dalam peace culture terdapat peace action yakni menyentuh semua jenis aktivitas, usaha dan inisiatif yang secara nyata ingin memajukan kedamaian secara menyeluruh dan bermartabat (Sunaryo Kartadinata, dkk, 2015: 21). Dengan kata lain, akan masuk wilayah penyebutan "peace culture" manakala di dalamnya sudah tercipta pembiasaan peace action yang nyata, tulus, murni, tidak ada nuansa pemaksaan dan manipulatif. Manakala masih terdapat nuansa pemaksaan dan manipulatif tidak akan disebut sebagai peace culture (budaya damai).

Hal yang terjadi pada para pekerja pembuat genting Sokka adalah masuk pada ranah peace culture, hal ini dikarenakan di dalamnya sudah mengalir suasana peace action yang sifatnya murni, tulus dan penuh kesadaran diri untuk berbuat yang mengarah pada penciptaan keharmonisan dalam kerja, tanpa adanya pemaksaan dan manipulasi. Ada beberapa bukti nyata, kondisi kerja pada area pembuatan genting Sokka masuk pada penyebutan peace culture dan peace action, yakni:
Pertama, Menunjukkan keramahtamahan dan kegembiraan dalam kerja yang sifatnya tulus "tidak dibuat-buat." Hal ini dapat dibuktikan dengan interaksi antara pekerja laki-laki dan pekerja perempuan yang akrab, tanpa mengedepankan egoisitas diri.

Kedua, Menunjukkan ketajaman perhatian, hal ini dapat dilihat dari perhatian yang besar yang ditunjukkan para pekerja lakilaki terhadap pekerja perempuan, dengan cara mengijinkan para pekerja perempuan untuk lebih sering istirahat, tidak dibolehkannya mereka para pekerja perempuan untuk ikut menyusun genting mentah yang akan dibakar.

Ketiga, Menunjukkan keadilan, hal ini dapat dilihat dari pembiasaan (conditioning) yang sudah terbentuk, yang mana mengarahkan pada tugas dan kerja yang ideal antara pekerja laki-laki dan pekerja perempuan, yang tidak disamaratakan antara pekerjaan yang seharusnya dikerjakan laki-laki dan yang tidak seharusnya dikerjakan pekerja perempuan. Hal ini menunjukkan bahwa konteks "keadilan" yang dimaksud adalah "tidak ada penyamarataan kerja” melainkan pekerjaan disesuaikan dengan kekuatan dan keahlian masing-masing yang dimiliki oleh pekerja laki-laki dan perempuan, dan yang demikian sudah terbentuk di area pembuatan genting Sokka Kebumen.

Keempat, Menunjukkan empati dan perasaan menyatu/bersaudara. Hal ini dibuktikan dengan suasana guyub rukun, dan adanya sense of tolerant antara sesama pekerja dan keluarga dari para pekerja.

Apabila diperhatikan secara seksama, para pekerja baik laki-laki maupun perempuan samasama memiliki keinginan yang sama yakni keinginan untuk memenuhi kebutuhan keamanan (need for self security), kebutuhan afiliasi sosial (need for sociality) dan kebutuhan cinta-memiliki (need for love and belongingness), dan ending-nya mengarah kepada kebutuhan aktulisasi diri (self 
actualization) (Hasyim Muhammad, 2002:71).Dalam tataran idealitas, seorang pekerja yang terpenuhi kebutuhan-kebutuhan tersebut akan menghantarkan kepada sikap dan perbuatan yang matang dalam area/zona kerja. Sehingga kondisi yang demikian mengarahkan pada budaya kerja yang aman, damai dan sejahtera. Dengan demikian titik penegasannya adalah semua pekerja harus "memiliki keinginan dan harapan yang sama” yakni keinginan dan harapan untuk membentuk bangunan kerja yang damai dan mendamaikan sesama.

Dengan kata lain, apabila di dalam suatu komunitas kerja tidak tercipta daya kematangan/kedewasaan kerja dan tidak terpenuhinya keinginan bersama untuk memenuhi berbagai kebutuhan yang telah disebutkan di atas, hal yang akan atau justru telah terjadi adalah ketidakharmonisan kerja, ketimpangan gender dalam kerja, dan ketidakadilan dalam kerja. Problem yang demikian banyak terjadi di lapangan.

\section{Pendidikan Kedamaian (Peace Education) Sebagai Akar Budaya "Keharmonisan Kerja Berbasis Keadilan Gender" pada Area Pembuatan Genting Sokka Kebumen}

Hal yang terpenting untuk mengarahkan pada budaya kerja yang aman dan damai dan menjauhi label "ketimpangan gender" atau "ketidakadilan gender" adalah pengembangan pendidikan kedamaian (peace education) dalam kerja. Hal ini ditunjukkan melalui budaya kerja yang aman dan harmonis pada area pembuatan genting Sokka di Kebumen. Pondasi utama yang dikedepankan adalah budaya damai (peace culture) yang bersumber kepada pendidikan kedamaian (peace education). Pada kenyataannya kondisi kedamaian dalam kerja di area Sokka sudah bersifat turun temurun. Hal ini ditegaskan oleh Ibu Rofiatun, yang menyatakan bahwa "para pekerja di sini sifatnya turun-temurun, bahkan ada dari mereka yang sudah bekerja sejak SMP, karena tidak melanjutkan sekolah yang kemudian ikut bekerja menjadi pekerja pembuat genting." Masih menurut Ibu Rofiatun, sejak awal bekerja rata-rata para perempuan dan lakilaki sudah mendapatkan wejangan baik dari orang tua pendahulunya (sudah dicontohkan) atau di dalam zona kerja itu sendiri-yang disampaikan oleh pekerja yang lebih senioruntuk bekerja dengan santun, bijaksana, terbuka, tanggung jawab, dan mengedepankan kedamaian bukan egoisitas diri. Meski pendidikan kedamaian yang diterapkan tidak secara formal sebagai contoh menggunakan media workshop, seminar atau pelatihan tetapi kondisi real di lapangan justru bersifat aplikatif, bukan teoritis, dan berjalan/mengalir dengan kondusif. (Wawancara dengan ibu Rofiatun, Perempuan pembuat genting Sokka dari Desa Kebulusan, wawancara dilakukan pada tanggal 13 September 2015 di lokasi pembuatan genting Desa Kebulusan, Pejagoan).

Ada beberapa cara yang dilakukan oleh masyarakat pembuat genting di Sokka Kebumen untuk melestarikan budaya damai dalam kerja dengan pendekatan pendidikan kedamaian (peace education) yang diharapkan terus turuntemurun, yakni: Pertama, menginternalisasikan ajaran kedamaian kepada anak-anak di rumah. Menurut Ibu Munginah, rata-rata dari para ibu pekerja pembuat genting tatakala di rumah memberi ajaran kedamaian kerja kepada anakanak mereka. Beberapa pernyataan yang dimunculkan seperti: gendo/thole'sesuk nek kowe wis gede, ojo dadi wong wedok lan wong lanang sing demen kerjone nakali wong (artinya; mba dan mas, besok kalau kamu sudah besar, jangan menjadi orang yang apabila bekerja menjadi pekerja yang suka membuat kerusuhan bagi orang lain). Ada juga yang menyampaikan "ndo/thole, dadio tukang gawe sing apik, sing disenengi wong liyo, ajo nakal utamane marang pekerja wedok, sing dadi wong kuwi kudu kerjo sing sabar, ngajeni wong liyo, niscoyo kowe ugo diajeni wong liyo (artinya: mba dan mas, kalau menjadi pekerja, jadilah pekerja yang disenengi 


\section{8-30 | HARKAT: Media Komunikasi Islam Tentang Gender dan Anak, 11 (1), 2015}

orang lain, jangan nakal, terutama kepada pekerja perempuan. Jadi orang itu harus kerja dengan sabar, menghormati orang lain, maka niscaya kamu juga akan disukai/dihormati orang lain). (Wawancara dengan ibu Munginah, Perempuan pembuat genting Sokka dari Desa Klirong, wawancara dilakukan pada tanggal 14 September 2015 di lokasi pembuatan genting Desa Klirong).

Kedua, membawa langsung para anak ke lokasi kerja, hal ini penulis melihat sendiri pada saat observasi, di mana banyak para ibu pekerja pembuat genting yang membawa anak-anak mereka ke lokasi kerja. Karena para anak di bawa langsung ke tempat kerja, secara otomatis mereka pun melihat langsung "budaya kerja” yang guyub dan santun. Para anak tidak hanya sekali atau dua kali saja bermain di tempat kerja ibunya tetapi berkali-kali, yang secara otomatis apa yang dilihat secara tidak langsung masuk ke alam bawah sadar anak, bahwa "saya nantinya di tempat kerja manapun harus santun dan memuliakan sesama, sebagaimana di tempat kerja ibu."Apalagi masa kanak-kanak adalah masa yang lentur yakni masa yang sesungguhnya mudah untuk dibentuk dan mudah untuk diarahkan, tergantung apa, siapa dan bagaimana yang mengarahkan.

Menurut Didin Wahyudin (dalam buku Sunarto Kartadinata,2015:64) dalam karyanya berjudul Pendidikan Kedamaian: Dimensi Teori dan Praksis menyatakan bahwa kedamaian yang bercirikan damai positif (positive peace) adalah bercirikan suasana di mana terdapat kesejahteraan (prosperity), kebebasan (freeness) dan keadilan (justice). Menurut Didin pandangan ini meyakini bahwa suasana dan kondisi damai hanya dapat terjadi apabila terdapat suasana batin yang bercirikan kesejahteraan, kebebasan dan keadilan di dalam masyarakat. Tanpa itu, kedamaian yang hakiki tidak akan pernah terjadi.
Lain halnya dengan Darmiyati Zuchdi (2010: 30-31) yang menyatakan bahwa suasana kedamaian haruslah diusahakan, dibentuk dan diberdayakan. Salah satunya dengan mengembangkan pendidikan kedamaian (peace education) terutama sejak dini kepada anak. Karena dengan semakin suburnya perilaku yang mendamaikan maka akan semakin subur pula keharmonisan dalam berafiliasi, terutama di tempat kerja. Suasana kedamaian yang harusnya diusahakan, dibentuk dan diberdayakan sejak dini adalah: Pertama, membentuk anak untuk bersikap dan berperilaku peduli kepada sesamanya. Kedua, membentuk anak untuk gemar menciptakan suasana tidak mengadili pihak lain. Ketiga, membentuk anak untuk mengembangkan perasaan turut memiliki. Keempat, membentuk anak untuk mengembangkan kesadaran akan tujuan. Kelima, membentuk anak untuk mengembangkan sifat toleran dan sabar. Keenam, membentuk anak untuk bersifat bijaksana. Ketujuh, membentuk anak untuk mengembangkan rasa simpati dan empati kepada sesama.

Kondisi yang disampaikan oleh Darmiyati Zuchdi setidaknya sudah diupayakan dan diusahakan secara turun temurun oleh para perempuan pekerja pembuat genting Sokka "untuk membekali sejak dini anak-anak mereka" dengan pendidikan kedamaian. Hal ini dapat dilihat dari wejangan-wejangan yang aktif diberikan para Ibu kepada anak-anaknya untuk bersikap adil kepada sesamanya, terutama kepada kaum hawa, selain itu untuk mengembangkan sikap toleran dan sabar serta mengembangkan diri untuk bersikap simpati dan empati. Selain berupa wejangan para ibu sudah menunjukkan dan memberi contoh (pro sosial) secara langsung kepada anak-anak mereka dengan membawa mereka ke tempat kerja. Dengan demikian ditegaskan bahwa para ibu pembuat genting sudah menerapkan apa yang diharapkan oleh Darmiyati Zuchdi. 
Belajar Nilai Kompherensif Pendidikan

Kedamaian (Peace Education) dari Para Pekerja Pembuat Genting Sokka Kebumen

Apabila melihat pemaparan di atas, terlihat bahwa kebiasaan keharmonisan kerja yang terlaksana di area pembuatan genting Sokka dapatlah diteladani. Meski belum terlalu banyak digali-sifatnya hanya permukaan saja-tetapi setidaknya apa yang telah ditunjukkan oleh penulis sejatinya dapat dijadikan role/model bagi para pekerja lain untuk mempelajari budaya hamonisasi kerjanya. Hal ini dikarenakan membentuk keharmonisan kerja anatara pekerja laki-laki dan perempuan tidaklah mudah, selain itu membuka kesadaran diri (self awwarness) dari masing-masing para pekerja untuk berperilaku santun, damai dan mendamaikan tidak pula mudah. Oleh karena itulah, apa yang ditampakkan oleh para pekerja di area pembuatan genting Sokka adalah nyata, dan dapat dijadikan sebagai inspiring to the working's harmony.

Ada beberapa hal yang dapat dipelajari dari area pembuatan genting Sokka Kebumen yang menerapkan metode kompherensif pendidikan kedamaian, yakni:

Pertama, adanya inkulkasi nilai (penanaman nilai). Penanaman nilai yang dilakukan tidak berwujud indoktrinasi, yang jelas-jelas bertentangan dengan konsepsi inkulkasi nilai itu sendiri. Tetapi inkulkasi nilai yang diterapkan adalah "inkulkasi nilai terbuka" yang bersifat mencerahkan (insight) dan memahamkan (understanding) bukan memaksa atau pula menekan. Hal ini dapat dilihat dari santunnya para ibu membekali anak-anak mereka dengan pemahaman dan pencerahan untuk bekerja dengan hati, bukan bekerja dengan emosi atau egoisitas diri, apalagi sampai memarginalisasikan kaum perempuan. Hal ini merupakan wujud inkulkasi nilai yang seharusnya diterapkan sejak dini kepada anak. Sehingga nantinya ketika si anak besar, mereka sudah mengerti apa yang harus dilakukan selaras dengan wejangan sang orang tua.

Dalam hal ini pula, hal yang seharusnya dipelajari oleh para pekerja di tempat lainnya adalah memberi penanaman nilai untuk menciptakan persamaan /keselarasan, keadilan, dan menjauhkan dari pemarginalisasian dan ketidakadilan dalam kerja kepada anak-anak mereka. Hal ini perlu dan sangat penting diberikan, utamanya dalam sekup lingkungan rumah, lingkungan yang terdekat dengan anak.

Kedua, keteladanan nilai. Hal yang dapat dipelajari lainnya dari area pembuatan genting Sokka adalah suburnya peteladanan nilai yang ditunjukkan oleh para pekerja. Di mana kondisi yang demikian pantas dan patut dicontoh oleh para pekerja di tempat-tempat lainnya. Atau dapat diadopsi oleh para pemangku kebijakan "pemilik tempat kerja" untuk menciptakan keharmonisan kerja yang sama. Keteladanan yang pantas diadopsi adalah keteladan regulasi diri (self regulation) dari masing-masing pekerja. Mereka mampu menekan egoisitas diri dengan baik, mampu membuka kesadaran diri untuk bersikap bijaksana dan menerima antara sesama, yang hal ini belum tentu terjadi pada tempattempat kerja lainnya. Terkadang banyak dari para pekerja yang menerapkan senioritas dan yunioritas, atau garis atas bawah, atau ada pula yang menunjukkan ketidakadilan/ketimpangan gender, yang kondisi itu semua justru tidak mendamaikan tetapi meresahkan. Dengan percontohan dari area pembuatan genting Sokka di atas setidaknya menjadi gambaran nyata untuk membuat area kerja menjadi nyaman, dan utamanya mampu berpihak kepada kaum perempuan.

Ketiga, Hal yang dapat dipelajari lainnya adalah pengembangan empati. Di area genting Sokka hal yang menonjol adalah para pekerja yang memiliki pengembangan empati yang baik. Kondisi demikian belum tentu ditemukan pada area kerja di tempat lain. Terkadang di lokasi 
kerja lainnya, bersifat "nafsi-nafsi" tanpa adanya kerekatan sosial, yang pada akhirnya menjadi pemicu konflik berkepanjangan. Sehingga tidak salah rasanya apabila mempelajari keharmonisan kerja yang ada di area pembuatan genting Sokka Kebumen, terutama bagi kaum muda usia produktif kerja, agar berupaya membiasakan diri untuk menciptakan kenyamanan dan kedamaian kerja di manapun lokasi kerjanya.

\section{PENUTUP}

Berdasarkan pemaparan di atas, terlihat jelas bahwa untuk belajar menciptakan harmonisasi kerja, tidak harus berbiaya mahal. Bahwa dengan menteladani keharmonisan kerja yang diciptakan oleh para pekerja $\mathrm{di}$ area pembuatan genting Sokka yang berbiaya murah, dapat dijadikan gambaran nyata, bahwa harmonisasi kerja antara pekerja perempuan dengan pekerja laki-laki memang ada. Di sisi lain, adalah nyata pula bahwa pendekatan yang digunakan adalah pendekatan pendidikan kedamaian (peace eduation) yang menjadi pondasi dasar rekatnya hubungan antara pekerja laki-laki dan pekerja perempuan, serta yang menjadi dasar pula keharmonisan kerja berbasis keadilan gender.

\section{DAFTAR PUSTAKA}

Darmiyati Zuchdi, Humanisasi Pendidikan, Jakarta: Bumi Aksara, 2010

Hasyim Muhammad, Dialog Antara Tasawuf dan Psikologi; Telaah Pemikiran Psikologi Humanistik Abraham Maslow, Semarang, Wali Songo Press: 2002

Jurnal Pendidikan Islam (JPI), Gender dan Pendidikan Islam, UIN Sunan Kalijaga, Yogyakarta, 2014

Siti Ruhaini Dzuhayatin, Rekronstruksi Metodologis Wacana Kesetaraan Gender dalam Islam, Yogyakarta: PSW Sunan Kalijaga, 2002

Sunaryo Kartadinata, dkk., Pendidikan Kedamaian, Bandung: Rosdakarya, 2015

\section{Artikel}

Sejarah Genteng Sokka, www.suaramerdeka.com 